\title{
Post-fire soil nutrient dynamics in a tropical dry deciduous forest of Western Ghats, India
}

\author{
Satyam Verma ${ }^{1,2}$, Dharmatma Singh ${ }^{1}$, Ajeet Kumar Singh ${ }^{1}$ and Shanmuganathan Jayakumar ${ }^{1 *}$
}

\begin{abstract}
Background: The effect of forest fire on soil is complex and relatively less understood than its above ground effect. Understanding the effect of fire on forest soils can allow improving management of valuable forest ecosystems as adequate and proper information is very important for efficient management. We have studied the recovery of soil properties after fire, using a chronosequence approach (two, five and fifteen years after fire and control). Soil samples were collected from each plot of four fire patches (B0, B2, B5 \& B15) from three different depths viz. 0-10 (Top), 10-20 (Middle), and 20-30 cm (Bottom).

Results: Soil organic carbon was lower than unburned plots after the fire and could not recover to the level of unburned plot (BO) even in 15 years. Total N, available $\mathrm{P}$, and extractable $\mathrm{K}$ were lower 2-years and 5-years after the fire but are higher than unburned plot after 15-years. Available nitrogen $\left(\mathrm{NO}_{3}{ }^{-}\right.$and $\left.\mathrm{NH}_{4}{ }^{+}\right)$remain unchanged or higher than B0 in burned patches. Soil pH, Bulk Density, Water Holding Capacity, and Electrical Conductivity was lower initially after the fire. Forest fires have affected soil properties considerably. The response of soil properties varied with years after fire and soil depth.
\end{abstract}

Conclusion: Forest fires occur very frequently in the study area. Significant quantities of carbon and total nitrogen are lost to the atmosphere by burning of litter, duff, and soil OM. Because nitrogen is one of the most important soil nutrients, the recapture of $\mathrm{N}$ lost by volatilization during a fire must receive special attention. Long-term studies are required to better understand the recovery of soil nitrogen.

Keywords: Soil properties, Western Ghats, Tropical dry deciduous Forest, Forest fire, Forest soils

\section{Background}

Fire is a significant ecological event that can produce variable effects on forest ecosystem (Whelan 1995; Keane et al. 2002). The role of fire in the forest is to act as an extrinsic disturbance factor (Crutzen and Goldammer 1993). It is a key disturbance that affects succession by selecting and regenerating plants, recycles nutrients, maintains diversity, decreases biomass, controls insects, triggers and regulates plant and animal interactions and most importantly affects biological and biogeochemical processes (Agee 1993; Crutzen and Goldammer 1993; Mutch 1994; Keane et al. 2002; Verma and Jayakumar

\footnotetext{
* Correspondence: jayakumar.eco@pondiuni.edu.in

${ }^{1}$ Environmental Informatics and Spatial Modeling Lab, Department of Ecology and Environmental Sciences, School of Life Sciences, Pondicherry University, Puducherry, India

Full list of author information is available at the end of the article
}

2015, 2018). Forest fires can also have global consequences by playing an important role in the global carbon cycle (Thonicke et al. 2001). The effect of forest fire on soils is complex and relatively less understood than its above ground effect (DeBano et al. 1998).

Fire can influence various soil properties, involving the detrimental impact on soil structure and reduction in soil organic matter, reduced porosity and high $\mathrm{pH}$ (DeBano 1990; Certini 2005; Verma and Jayakumar 2012). Fire can reduce the number of soil nutrients in a forest by losses from volatilization, smoke, ash transport, leaching, and erosion. These changes can produce several secondary effects like increased hydrophobicity, decreasing infiltration rate and increasing runoff (Inbar et al. 2014; Jiménez-Pinilla et al. 2016). This may result in accelerated soil erosion (DeBano 2000). In the long term, fires may also contribute to the reduced availability 
of nutrients because nutrients released from organic matter and microbial biomass are expected to be removed from the ecosystem by runoff and leaching (Wüthrich et al. 2002; Miesel et al. 2012).

The factors which produce the wide range of responses in soil include pre-burn environment, fire behavior, fire season, and pre-fire and post-fire climatic conditions such as time of year, amount and extent of rainfall (Clark 2001). During burning, plant cover and litter layers are consumed, and the mineral soil is heated, resulting in changes in physical, chemical, mineralogical, and biological soil properties (Fonseca et al. 2017). The combination of combustion and heat transfer produces sharp temperature gradients in the topsoil profile (Certini, 2005).

Organic matter loss is the most spontaneous change that soils experience during a fire (Certini 2005). The organic horizon is an important part of environmental sustainability as it provides a protective soil cover that mitigates soil erosion, helps in regulating soil temperature, provides habitat and substrates for soil biota and is an important source of readily mineralizable nutrients (Neary et al. 1999). The impact of forest fire on soil organic matter (SOM) is extremely variable from complete destruction of SOM to partly scorch, depending on fire severity, aridity of the surface OM and type of fire (Neary et al. 1999; González-Pérez et al. 2004; Fonseca et al. 2017). The impact of forest fire on SOM also depends on soil moisture, soil type, and nature of the burned materials (González-Pérez et al. 2004).

The direct effect of forest fire on soil macronutrients is their loss through volatilization in high temperature, ash entrapment in smoke columns, leaching and erosion (Neary et al. 1999; Certini 2005). Fire may also affect soil nutrient status directly by addition of available nutrients and indirectly by changing the soil environment (Marion et al. 1991). Nutrients present in live twigs and dead plant materials can either be lost by volatilization during a fire or released and deposited on the soil surface in a highly soluble form. These highly soluble forms of nutrients on the soil surface may be used for plant growth or simply lost by erosion (DeBano and Conrad 1978). This nutrient enrichment is mainly limited to the topsoil $(0-5 \mathrm{~cm})$ and only soluble $\mathrm{N}$ seemed to increase in the sub-surface soil $(5-10 \mathrm{~cm})$ (Marion et al. 1991). The most important short-term effects of the forest fire are the upsurge in the soil solution concentrations and leaching of mineral forms of nitrogen, sulfur, and phosphorus (Murphy et al. 2006) however, the total nitrogen decreases (Verma and Jayakumar 2012). Fire can also increase soil nutrient levels, particularly non-volatile elements ( $\mathrm{K}, \mathrm{P}, \mathrm{Ca}, \mathrm{Mg}$, etc.) as well as total concentrations after low-intensity fires (Hough 1981; Schoch and Binkley 1986).
The role of forest fire in the nutrient dynamics and global carbon cycle has been comprehensively studied in both natural forests and plantations of boreal and temperate regions, as well as for slash and burn cultivation in tropical regions (Carter and Foster 2004; Meigs et al. 2009). However, effects of forest fire in the tropical forests are not very clear as the effects of fire on tropical forest soils can be extremely variable and there are very limited studies on the impact of forest fire on tropical forest across the world (Verma and Jayakumar 2012, 2018) and almost none in Indian tropical dry deciduous forest. Understanding the effect of fire on forest soils can allow improving management of valuable forest ecosystems as adequate and proper information is very important for efficient management. It is assumed that fire may produce a varied response in total and available plant nutrients after different years of burning. Hence the present study is aimed to understand the changes in soil properties in a fire chronosequence after two, five and fifteen years of a fire event. The main questions are as follows: 1) how fire affects physical and chemical properties of soil in tropical dry deciduous forests and 2) how much time they require to reach the level of the unburned forest?

\section{Materials and methods}

\section{Study area}

This study was conducted in Mudumalai Tiger Reserve (MTR). MTR is situated at the tri-junction of Tamilnadu, Kerala and Karnataka states on the northeastern slope of Nilgiri part of the Western Ghats descending to Mysore plateau. MTR spreads in an area of $321 \mathrm{~km}^{2}$, which is a part of Nilgiri Biosphere Reserve (NBR). It is adjoining Wayanad wildlife sanctuary on the northwest, Bandipur tiger reserve on the north, Sigur and Singara reserve forests in the south and east respectively. The MTR is situated between $11^{\circ} 32^{\prime} \& 11^{\circ} 43^{\prime} \mathrm{N}$ and $76^{\circ}$ $22^{\prime} \& 76^{\circ} 45^{\prime} \mathrm{E}$ (Fig. 1). MTR is one of the few reserves in India with a rich flora and fauna and varied terrain. In general, MTR plays a significant role in biodiversity conservation; particularly large mammals with its flora diversity which largely depends on available soil nutrient.

The terrain is undulating with an elevation ranging from about 851 to $1258 \mathrm{~m}$ Above Sea Level (ASL) with an average elevation of $1000 \mathrm{~m}$. Broadly two types of soils are recognized in the sanctuary; black sandy loam containing 50\% sand and gravel and a red heavy loam soil. Red soil is generally confined in the southern part of the MTR where rainfall is heavier. There are three different seasons recognized with annually two monsoons i.e. south-west and north-east. January to May is a dry summer season; the southwest monsoon starts in May and ends by August whereas the north-east monsoon starts in September and ends by December (Suresh et al. 


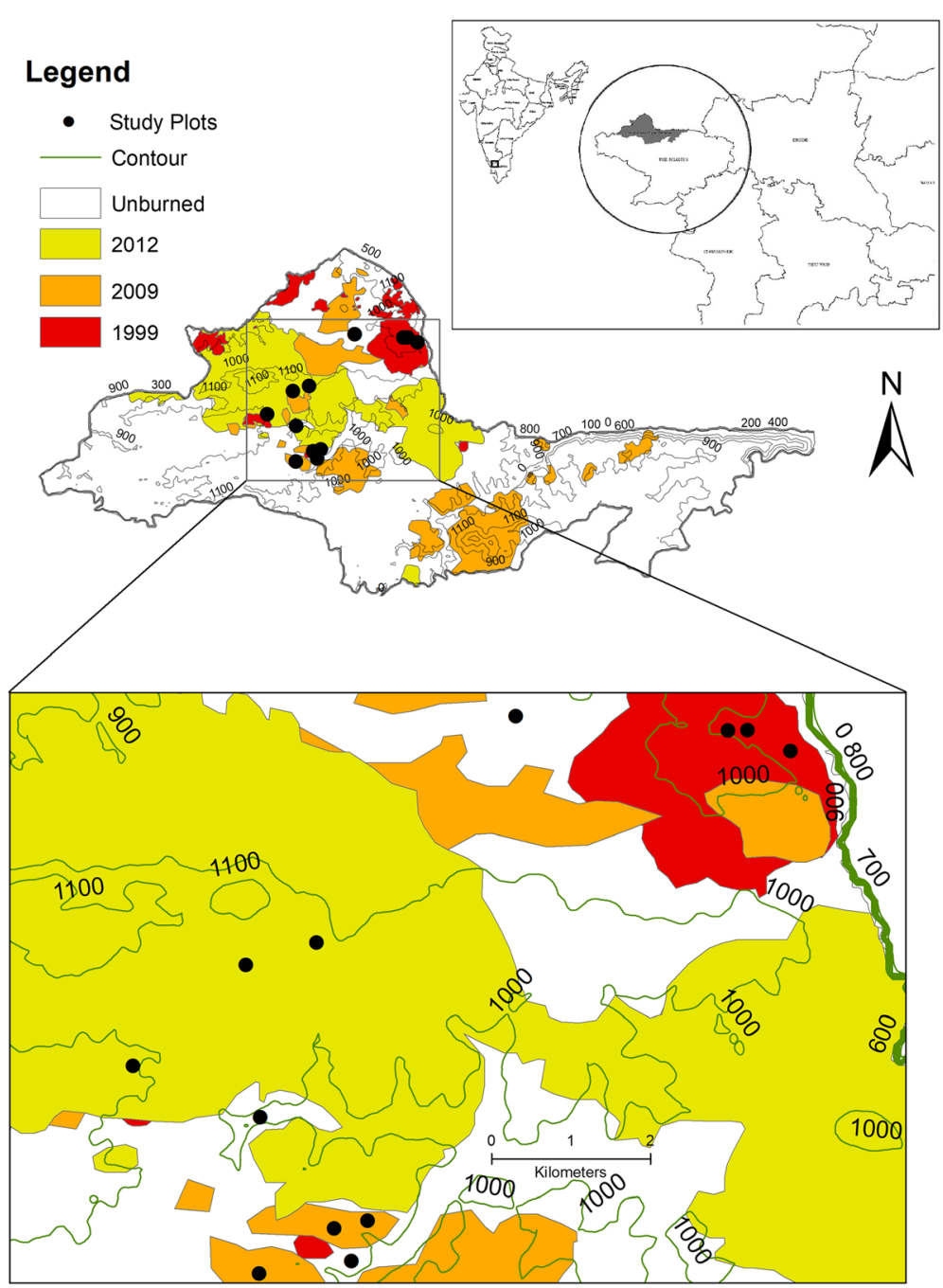

Fig. 1 Location map of the study area

2010). Annual rainfall ranges from about $800 \mathrm{~mm}$ in the east to $2600 \mathrm{~mm}$ in the west. The average maximum temperature in MTR varied from $25.4 \pm 0.5^{\circ} \mathrm{C}$ in August to $31.0 \pm 0.3^{\circ} \mathrm{C}$ in April and average minimum temperature from $13.9 \pm 0.5^{\circ} \mathrm{C}$ in January to $18.1 \pm 0.6^{\circ}$ $\mathrm{C}$ in April (Dattaraja et al. 2013).

The vegetation types in MTR are classified into southern tropical dry thorn forest, southern tropical dry deciduous forest, southern tropical moist deciduous forest, southern tropical semi-evergreen forest, moist bamboo brakes and riparian forest (Champion and Seth 1968). Annual dry season fires are common all over MTR. Most of these are surface fires. The fire comes in MTR in the months of January to mid-May. The causes of these fires are poaching, antler collection, grazing, tourism, estates and settlements in and around the reserve (Srivastava et al. 2014). The inflammable material continuously cast down by the deciduous trees offers even an accidental spark the chance of developing into an extensive and devastating fire.

\section{Fire mapping}

Toposheets (58 A6 and 58A10) of MTR were collected from the Survey of India at 1:50,000 scales. Burned area maps for the period between 2001 and 2012 were collected from the forest department, Tamil Nadu. Burned area maps for 1999, 2000 and 2013 were prepared using Multi-temporal satellite data of Landsat 5 Thematic Mapper (TM), acquired on 2, February 1999 and 7, April 1999, Landsat 7 Enhanced Thematic Mapper Plus (ETM+) acquired on 28 January 2000, 1 April 2000, 17, April 2000, 3 May 2000, 31 January 2013 and Landsat 8 Operational Land Imager Thermal Infrared Sensors (OLI-TIRS) acquired on 13 April 2013 from United States Geological Survey (USGS) Earth Explorer (https://earthexplorer.usgs.gov/). Supervised classification technique was adopted to prepare fire maps 
Table 1 Description of study sites and fire classes

\begin{tabular}{llllll}
\hline Class Code & Fire Class & Year of occurrence & Number of Plots & Basal area (SD) $\left(\mathrm{m}^{2}\right.$ ha $\left.^{-1}\right)$ & Stem density $(\mathrm{SD})\left(\mathrm{ha}^{-1}\right)$ \\
\hline B0 & Unburned & Never Burned in Past 15 Year & 3 & $36.81(2.19)$ & $407(41.63)$ \\
B2 & Two year old & 2012 & 3 & $24.88(3.25)$ & $370(52.91)$ \\
B5 & Five year old & 2009 & 3 & $29.70(7.21)$ & $463(32.15)$ \\
B15 & Fifteen year old & 1999 & 3 & $25.49(5.85)$ & $570(6.46)$ \\
\hline
\end{tabular}

based on the shortwave infrared composite image (band combination 7-4-1 in RGB for Landsat ETM+) to delineate the burned area. Maximum likelihood (ML) classification method was used for the supervised classification. The ML algorithm is a parametric classifier that presupposes that the training data values for each class in each spectral band are normally distributed (Jensen 2005). The ML classification is achieved by allocating pixels to their most likely class of membership (Atkinson and Lewis 2000). Representative training sites were extracted before the classification through visually selecting pixels representing burned and unburned surfaces using ERDAS Imagine 2011 software. Burned area maps for every year were converted into raster data and combined using map algebra to prepare fire frequency maps using spatial analyst module in ArcGIS 10 software.

From the fire frequency map, unburned pixels and burned once between 1999 and 2013 were selected. The unburned pixels were grouped into Unburned (B0), pixels that burned only once in 2012, 2009 and in 1999 were designed as 2-y-old burn (B2), 5-y-old burn (B5) and 15-y-old burn (B15).

\section{Study design and data collection}

The study was carried out only in the deciduous forest in MTR. Four classes (B0-Unburned, B2-Burned two years ago, B5-Burned five years ago and B15-Burned fifteen years ago) were prepared to study the impact of forest fire. The soil was black sandy loam in all patches. All the patches were at the elevation of 900-1100 m ASL and slope was gentle. For each class, three 0.1 ha square plots were laid randomly and there were no significant environmental differences within these plots. Soil samples were collected from all burned and unburned classes (Table 1). Five samples were collected from each plot from three different depths viz. 0-10 (Top), $10-20$ (Middle), and $20-30 \mathrm{~cm}$ (Bottom). Samples were collected between September 2013 and January 2014. Soil samples were immediately transported to the lab to analyze for total nitrogen and available nitrogen. Remaining soil samples were air-dried and mixed to get composite samples. Air-dried soil was sieved through $2 \mathrm{~mm}$ sieve.

\section{Soil analysis}

Soil $\mathrm{pH}$ and EC were analyzed in aqueous soil extract (1:2, Soil: Water). Soil organic carbon content was determined by dichromate oxidation method described by Walkley and Black (1934). Water holding capacity was determined by water saturation method. Total nitrogen was analyzed by the Kjeldahl method. Nitrate $\left(\mathrm{NO}_{3}{ }^{-}\right)$content in the soil was determined by the method of Cataldo et al. (1975) using a spectrophotometer. Ammonium $\left(\mathrm{NH}_{4}{ }^{+}\right)$content in soil was also estimated by using Nessler's reagent $(\mathrm{K} 2 \mathrm{HgI} 4+\mathrm{NaOH})$ method as described by Weatherburn (1967).

Table 2 Result of the two-factor ANOVA (Fire class and soil depth) for the soil properties

\begin{tabular}{|c|c|c|c|}
\hline Soil Properties & Variables & F ratio & $p$-value \\
\hline \multirow[t]{3}{*}{$\overline{\mathrm{pH}}$} & Fire class & 13.129 & $<0.001$ \\
\hline & Depth & 3.712 & 0.039 \\
\hline & Fire $x$ Depth & 4.372 & 0.004 \\
\hline \multirow[t]{3}{*}{ EC } & Fire class & 25.989 & $<0.001$ \\
\hline & Depth & 2.851 & 0.077 \\
\hline & Fire x Depth & 0.342 & 0.908 \\
\hline \multirow[t]{3}{*}{ Bulk density } & Fire class & 3.898 & 0.021 \\
\hline & Depth & 4.518 & 0.022 \\
\hline & Fire x Depth & 1.044 & 0.422 \\
\hline \multirow[t]{3}{*}{ Organic carbon } & Fire class & 5.994 & 0.003 \\
\hline & Depth & 6.736 & 0.005 \\
\hline & Fire $x$ Depth & 1.478 & 0.228 \\
\hline \multirow[t]{3}{*}{ Total nitrogen } & Fire class & 24.181 & $<0.001$ \\
\hline & Depth & 4.994 & 0.015 \\
\hline & Fire $x$ Depth & 2.036 & 0.100 \\
\hline \multirow[t]{3}{*}{$\mathrm{NO}_{3}{ }^{-} \mathrm{N}$} & Fire class & 0.155 & 0.925 \\
\hline & Depth & 1.832 & 0.182 \\
\hline & Fire x Depth & 6.520 & $<0.001$ \\
\hline \multirow[t]{3}{*}{$\mathrm{NH}_{4}{ }^{-} \mathrm{N}$} & Fire class & 3.759 & 0.024 \\
\hline & Depth & 20.869 & $<0.001$ \\
\hline & Fire x Depth & 1.126 & 0.377 \\
\hline \multirow[t]{3}{*}{ Available P } & Fire class & 45.477 & $<0.001$ \\
\hline & Depth & 5.175 & 0.014 \\
\hline & Fire x Depth & 3.277 & 0.017 \\
\hline \multirow[t]{3}{*}{ Extractable K } & Fire class & 86.571 & $<0.001$ \\
\hline & Depth & 17.190 & $<0.001$ \\
\hline & Fire x Depth & 3.455 & 0.013 \\
\hline
\end{tabular}

Significant effects (at $\alpha=0.05$ ) are shown in bold type 

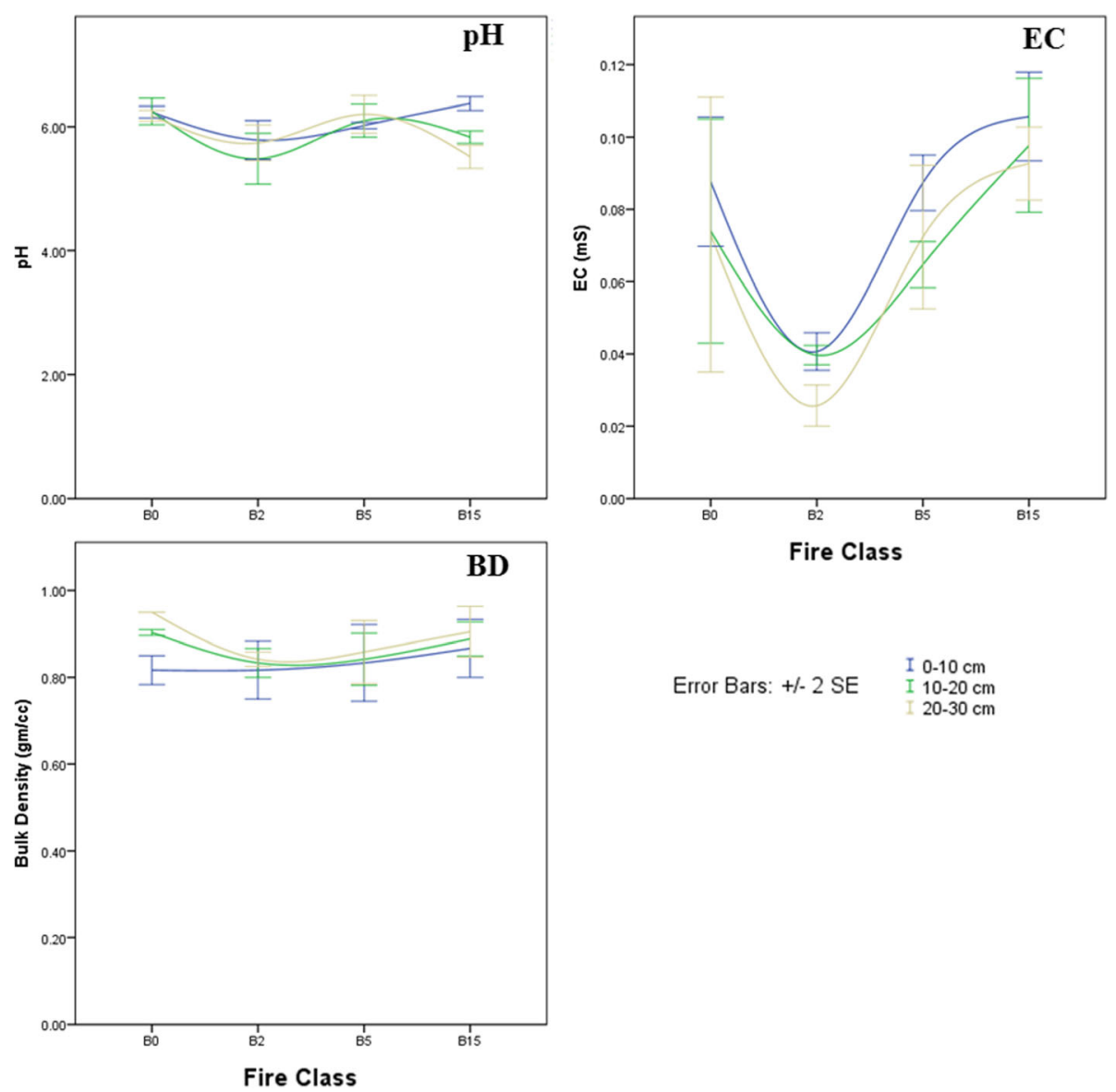

Fire Class

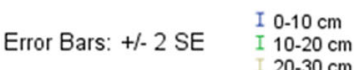

Fig. 2 Mean ( \pm SE) pH, Electrical Conductivity and Bulk Density

Absorbance (optical density) in each case was recorded using UV-visible spectrophotometer) at the wavelength of 410 and 420 and the $\lambda_{\max }$ values in the UV-Visible spectrum indicate the presence of nitrate and ammonium, respectively. Available phosphorus was determined by Bray extraction method (Bray and Kurtz 1945) using a spectrophotometer. Extractable potassium was determined by ammonium acetate extraction method using flame photometer.

\section{Statistical analysis}

Data were analyzed by a two-way analysis of variance (ANOVA) at which soil depth and fire chronosequence were selected as factors (Table 2). We tested both factor effects (soil depth and fire) and their potential interaction. The explained variance was partitioned using the type III sum of squares. Statistical analysis was done by SPSS 20 (IBM Corp., Armonk, NY, USA).

\section{Results}

Soil pH was $5.79 \pm 0.27$ in $\mathrm{B} 2$ which is lower than other burned classes including B0 in the top layer $(0-10 \mathrm{~cm})$. Soil $\mathrm{pH}$ was higher than Unburned in B15. A similar pattern was observed in the middle and bottom layers (Fig. 2). Soil pH showed significant variation across the depth and fire classes. Electrical conductivity was also lower two years after the fire in all layers. EC was higher than B0 in B5 and B15 classes in the top and bottom layers and in the middle layer, it was higher in B15 (Fig. 2).

Water holding capacity of soil was lower in B2 (48.26 $\pm 2.9 \%)$ in top layer compared to B0 $(54.83 \pm 3.09 \%)$. In B5 (51.62 $\pm 3.83 \%)$ and in B15 (54.19 $\pm 5.73 \%)$ it reached to the level of B0. In middle and bottom layers only B2 was lower than B0 and in none of the layer they are significantly different (Additional file 1). Bulk density did not change after fire in top layer but was lower after fire in the bottom layer (Fig. 2).

Organic carbon was significantly different in across the depth classes and fire classes. In all three layers, organic carbon was higher in B0 than burn classes. In the middle layer, organic carbon was recorded $1.33 \pm 0.16 \%$ in $\mathrm{B} 0$ and $0.94 \pm 0.04 \%$ in B2 (Fig. 3).

Total $\mathrm{N}$ was significantly low in B2 compared to B0 in the top and middle layer and recorded higher in B5 and B15 compare to B2. It was higher than B0 fifteen years after fire (from $0.11 \pm 0.01 \%$ in B0 to $0.12 \pm 0.01 \%$ in 

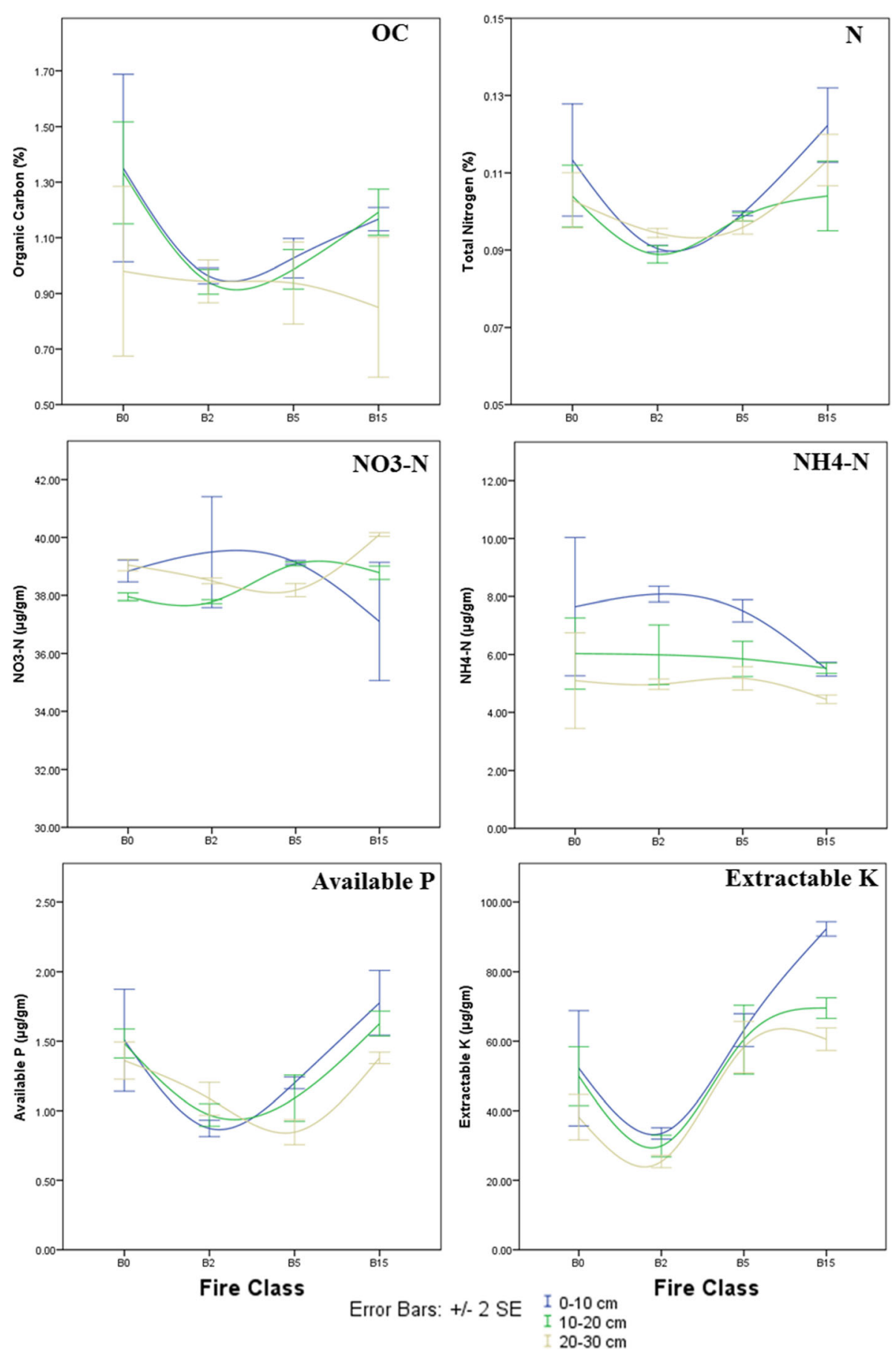

Fig. 3 Mean ( \pm SE) Organic Carbon, Total nitrogen, $\mathrm{NO}_{3}{ }^{-} \mathrm{N}, \mathrm{NH}_{4}{ }^{-} \mathrm{N}$, Available Phosphorus and Extractable Potassium in different fire classes

B15) in the top layer. Changes in bottom layer were similar to the top layer and middle layer though not significantly different from unburned (Fig. 3).

Available forms of nitrogen $\left(\mathrm{NO}_{3}{ }^{-}\right.$and $\left.\mathrm{NH}_{4}{ }^{+}\right)$did not change much after a fire. In the top layer, both $\mathrm{NO}_{3}{ }^{-}$ and $\mathrm{NH}_{4}{ }^{+}$were slightly higher after fire (in B2) and slightly lower in B5 and B15 compared to B0 (Fig. 3).
Whereas in mid-layer $\mathrm{NO}_{3}{ }^{-}$was lower in $\mathrm{B} 2$ but higher in B5 and B15. In the bottom layer, it was higher than B0 in SB15. In middle and bottom layers $\mathrm{NH}_{4}{ }^{+}$was lower than B0 in burn classes.

In top layer available phosphorus was recorded $1.51 \pm$ $0.32 \mu \mathrm{g} / \mathrm{gm}$ in B0, $0.87 \pm 0.05 \mu \mathrm{g} / \mathrm{gm}$ in B2 and $1.78 \pm$ $0.20 \mu \mathrm{g} / \mathrm{gm}$ in B15. In the middle layer and bottom layer 
also available phosphorus was lower in B2 but was higher than B0 in B15. Change in concentration of extractable potassium was very significant. In all soil depth, it was lower in B2 but was very significantly high in B15 (Fig. 3).

\section{Discussion}

Forest fires have affected soil properties considerably. The response of soil properties varied with years after the fire and soil depth. While the soils in our study are acidic in nature, the fire has reduced the soil pH. Results observed in this study agrees with data reported by Badía and Martí (2003) and Terefe et al. (2008). Terefe et al. (2008) have suggested that $\mathrm{pH}$ decrease initially with increasing temperature up to $200^{\circ} \mathrm{C}$ but started increasing with temperature rise to $500^{\circ} \mathrm{C}$. These outcomes possibly reflect a collective effect of desiccation and heating, which favors proton-reducing oxidation reactions (Sertsu and Sánchez 1978).

EC was lower in two-year-old burn but recorded higher in B5 and B15. The explanation for the reduction of EC in all the soil samples could be the collapse of the clay minerals, the formation of base oxides and the generation of coarse sand size particles, which can enclose base oxides. Water holding capacity of soil has shown a decreasing trend after a fire. Soil water holding capacity is one of the properties most affected by combustion during a forest fire. The main effect of fire on soil physical properties is to eliminate the storage capacity of water in the organic horizons (several $\mathrm{cms}$ ). Infiltration rates remain high at first but later decrease as there is a decrease in porosity (Imeson et al. 1992). High surface temperatures burn off organic materials and create vapors that travel downward in response to a temperature gradient and then condense on soil particles making them water repellent (Letey 2001). Bulk density was also slightly lower in middle and bottom layers but slightly higher in top layer after the fire. Bulk density increases due to the collapse of aggregates and clogging of voids by the ash and dispersed clay minerals that result in reduced soil porosity and permeability (Certini 2005).

Fire seems to decrease Organic carbon as a consequence of the pyrolysis of organic materials by heat (Orioli and Curvetto 1978; Almendros et al. 1990). The impact of fire on soil organic matter includes volatilization, charring, and oxidation (Giovannini et al. 1988). Substantial loss of organic matter occurs at 200$460^{\circ} \mathrm{C}$ (Giovannini et al. 1988).

Total $\mathrm{N}$ was significantly low after the fire compared to control. Generally, a noteworthy decrease in total $\mathrm{N}$ happens after fire in all studied fire classes, which is also suggested by Neff et al. (2005). Forest floor layers are a major reservoir of soil $\mathrm{N}$ and their removal during forest fires can cause substantial decreases in it (Driscoll et al. 1999).
Available forms of nitrogen $\left(\mathrm{NO}_{3}{ }^{-}\right.$and $\left.\mathrm{NH}_{4}{ }^{+}\right)$did not change much after a fire. It is suggested that the increase of available nitrogen, particularly $\mathrm{NH}_{4}{ }^{+}$, is generally short-lived and quick immobilization could reduce it after 6 months (Adams and Attiwill 1986).

Available P was lower than control in B2 but higher in B15. Losses of phosphorus by volatilization or leaching are small. Burning changes the organic pool of soil P to orthophosphate (Cade-Menun et al. 2000); the sole form of available P. Fire may be mineralizing organically bound $\mathrm{P}$ thus reducing extractable $\mathrm{P}$. Changes in concentration of extractable potassium were very significant. It decreased initially but increased fifteen years after fire.

\section{Conclusion}

Forest fires occur very frequently in MTR. Soil properties showed varied response after the fire. Soil organic carbon, nitrogen, available $\mathrm{P}$ and extractable $\mathrm{K}$ was lower 2-years after the fire but started recovering 5 -years after the fire. Whereas available forms of nitrogen were higher in 2-year old burn patch and lower in 15-year old burn patches. Significant quantities of carbon and total nitrogen are lost to the atmosphere by burning of litter, duff, and soil OM. Because nitrogen is one of the most important soil nutrients, the recapture of $\mathrm{N}$ lost by volatilization during a fire must receive special attention. Long-term studies are required to better understand the recovery of soil nitrogen. Availability of few plant nutrients increases after fire though some other nutrients are volatilized during combustion. Fire plays a significant role in the dynamics of forest ecosystems across the world. However, careful planning is necessary to assure that forests are not adversely affected by fire-related changes in soils.

\section{Additional file}

Additional file 1: Mean $( \pm S E)$ Water Holding Capacity $(\mathrm{WHC})$ in different fire classes. (TIF $37 \mathrm{~kb}$ )

\section{Abbreviations \\ ${ }^{0} \mathrm{C}$ : Degree Celsius; ASL: Above Sea Level; EC: Electrical Conductivity; ETM: Enhanced Thematic Mapper; Ha: Hectare; K: Potassium; ML: Maximum Likelihood; mm: Millimetre; MTR: Mudumalai Tiger Reserve; N: Nitrogen; NBR: Nilgiri Biosphere Reserve; OLI-TIRS: Operational Land Imager Thermal Infrared Sensors; OM: Organic Matter; P: Phosphorus; SD: Standard Deviation; SOM: Soil Organic Matter; TM: Thematic Mapper; USGS: United States Geological Survey; WHC: Water Holding Capacity}

\section{Acknowledgements}

We thank the Tamil Nadu Forest Department for granting us permission and the support of field assistants and forest staff for their help and cooperation. The first author thanks the University Grants Commission, New Delhi for providing the financial support for the Ph.D. research through Junior Research Fellowship (UGC letter No. F. 17-115/98 (SA-I) dated-11 June 2013).

Funding

Not applicable 


\section{Availability of data and materials}

Data will be made available on demand.

\section{Authors' contributions}

SJ and SV planned the work and did analysis and manuscript preparation. SV and DS Prepared Fire Maps. SV conducted field work. DS, AJ and SV did soil analysis. All authors read and approved the final manuscript.

\section{Ethical approval and consent to participate}

Not applicable

\section{Consent for publication}

Not applicable

\section{Competing interests}

The authors declare that they have no competing interests.

\section{Author details}

'Environmental Informatics and Spatial Modeling Lab, Department of Ecology and Environmental Sciences, School of Life Sciences, Pondicherry University, Puducherry, India. ${ }^{2}$ Present Address: Landscape Level Planning and Management, Wildlife Institute of India, Dehradun 248001, India.

Received: 14 December 2017 Accepted: 19 February 2019

Published online: 27 February 2019

\section{References}

Adams MA, Attiwill PM (1986) Nutrient cycling and nitrogen mineralization in eucalypt forests of South-Eastern Australia. Plant Soil 92(3):341-362

Agee JK (1993) Alternatives for implementing fire policy. In: roceedings, Symposium on fire in wilderness and park management, pp 107-112

Almendros G, González-Vila FJ, Martin F (1990) Fire-induced transformation of soil organic matter from an oak forest: an experimental approach to the effects of fire on humic substances. Soil Sci 149(3):158-168

Atkinson PM, Lewis P (2000) Geostatistical classification for remote sensing: an introduction. Comput Geosci 26:361-371

Badía D, Martí C (2003) Plant ash and heat intensity effects on chemical and physical properties of two contrasting soils. Arid Land Res Manag 17(1):23-4

Bray RH, Kurtz LT (1945) Determination of total, organic, and available forms of phosphorus in soils. Soil Sci 59(1):39-46

Cade-Menun BJ, Berch SM, Preston CM, Lavkulich LM (2000) Phosphorus forms and related soil chemistry of Podzolic soils on northern Vancouver Island. II. The effects of clear-cutting and burning. Can J For Res 30(11):1726-1741

Carter MC, Foster CD (2004) Prescribed burning and productivity in southern pine forests: a review. Forest Ecol Manag 191:93-109

Cataldo DA, Maroon M, Schrader LE, Youngs VL (1975) Rapid colorimetric determination of nitrate in plant tissue by nitration of salicylic acid 1 . Communications in Soil Science \& Plant Analysis 6(1):71-80

Certini G (2005) Effects of fire on properties of forest soils - a review. Oecologia 143:1-10

Champion HG, Seth SK (1968) Revised forest types of India. The government of India, New Delhi, 404

Clark B (2001) Soils, water, and watersheds. In: Fire Effects Guide. National Interagency Fire Center, USA

Crutzen PJ, Goldammer JG (1993) Fire in the environment: the ecological, atmospheric and climatic importance of vegetation fires. Report of the Dahlem Workshop, Berlin, 15-20 March, 1992. In Fire in the environment: the ecological, atmospheric and climatic importance of vegetation fires. John Wiley \& Sons

Dattaraja HS, Pulla S, Mondal N, Suresh HS, Bharanaiah CMB, Sukumar R (2013) Spatial interpolation of rainfall for Mudumalai Wildlife Sanctuary and Tiger Reserve, Tamil Nadu, India. Indian Institute of Science, Centre for Ecological Sciences. Technical Report 130. (Bangalore)

Debano LF (1990) The effect of forest fire on soil properties. Symposium on Management and Productivity of Western- Montane Forest Soil. 151-156, Boise, ID, USA

Debano LF (2000) The role of fire and soil heating on water repellency in wildland environments: a review. J Hydrol 231:195-206

Debano LF, Conrad CE (1978) The effect of fire on nutrients in a chaparra ecosystem. Ecology 59(3):489497
Debano LF, Neary DG, Ffolliott PF (1998) Fire effects on ecosystems. John Wiley \& Sons, USA

Driscoll KG, Arocena JM, Massicotte HB (1999) Post-fire soil nitrogen content and vegetation composition in sub-boreal spruce forests of British Columbia's central interior, Canada. Forest Ecol Manag 121(3):227-237

Fonseca F, de Figueiredo T, Nogueira C, Queirós A (2017) Effect of prescribed fire on soil properties and soil erosion in a Mediterranean mountain area. Geoderma 307:172-180

Giovannini G, Lucchesi S, Giachetti M (1988) Effect of heating on some physical and chemical parameters related to soil aggregation and erodibility. Soil Sci 146(4):255-261

González-Pérez JA, González-Vila FJ, Almendros G, Knicker H (2004) The effect of fire on soil organic matter-a review. Environ Int 30(6):855-870

Hough WA (1981) Impact of prescribed fire on understory and forest floor nutrients. Res. Note SE-303. Asheville, NC: US Department of Agriculture, Forest Service, southeastern Forest Experiment Station. 4 p, 303

Imeson AC, Verstraten JM, Van Mulligen EJ, Sevink J (1992) The effects of fire and water repellency on infiltration and runoff under Mediterranean type forest. Catena 19(3):345-361

Inbar A, Lado M, Sternberg M, Tenau H, Ben-Hur M (2014) Forest fire effects on soil chemical and physicochemical properties, infiltration, runoff, and erosion in a semiarid Mediterranean region. Geoderma 221:131-138

Jensen JR (2005) Introductory digital image processing: a remote sensing perspective. Prentice Hall, Upper Saddle River, NJ

Jiménez-Pinilla P, Lozano E, Mataix-Solera J, Arcenegui V, Jordán A, Zavala LM (2016) Temporal changes in soil water repellency after a forest fire in a Mediterranean calcareous soil: influence of ash and different vegetation type. Sci Total Environ 572:1252-1260

Keane RE, Ryan KC, Veblen TT, Allen CD, Logan JA, Hawkes B, Barron J (2002) The cascading effects of fire exclusion in Rocky Mountain ecosystems. Rocky Mountain futures: an ecological perspective, 133-152

Letey J (2001) Causes and consequences of fire-induced soil water repellency. Hydrol Process 15(15):2867-2875

Marion GM, Moreno JM, Oechel WC (1991) Fire severity, ash deposition, and clipping effects on soil nutrients in chaparral. Soil Sci Soc Am J 55(1):235-240

Meigs GW, Donato DC, Campbell JL, Martin JG, Law BE (2009) Forest fire impacts on carbon uptake, storage, and emission: the role of burn severity in the eastern cascades, Oregon. Ecosystems 12:1246-1267

Miesel JR, Goebel PC, Corace RG, Hix DM, Kolka R, Palik B, Mladenoff D (2012) Fire effects on soils in Lake states forests: a compilation of published research to facilitate long-term investigations. Forests 3:1034-1070

Murphy JD, Johnson DW, Miller WW, Walker RF, Carroll EF, Blank RR (2006) Wildfire effects on soil nutrients and leaching in a Tahoe Basin watershed. J Environ Qual 35(2):479-489

Mutch RW (1994) Fighting fire with prescribed fire: a return to ecosystem health. J For 92:31-33

Neary DG, Klopatek CC, Debano LF, Ffolliott PF (1999) Fire effects on belowground sustainability: a review and synthesis. Forest Ecol Manag 122(1):51-71

Neff JC, Harden JW, Gleixner G (2005) Fire effects on soil organic matter content, composition, and nutrients in boreal interior Alaska. Can J For Res 35(9): 2178-2187

Orioli GA, Curvetto NR (1978) The effect of fire on soil humic substances. Plant Soil 50(1-3):91-98

Schoch P, Binkley D (1986) Prescribed burning increased nitrogen availability in a mature loblolly pine stand. Forest Ecol Manag 14(1):13-22

Sertsu SM, Sánchez PA (1978) Effects of heating on some changes in soil properties in relation to an Ethiopian land management practice. Soil Sci Soc Am J 42(6):940-944

Srivastava SK, Saran S, De By RA, Dadhwal VK (2014) A geoinformation system approach for forest fire likelihood based on causative and anti-causative factors. Int J Geogr Inf Sci 28(3):427-454

Suresh HS, Dattaraja HS, Sukumar R (2010) Relationship between annual rainfall and tree mortality in a tropical dry forest: results of a 19-year study at Mudumalai, southern India. Forest Ecol Manag 259(4):762-769

Terefe T, Mariscal-Sancho I, Peregrina F, Espejo R (2008) Influence of heating on various properties of six Mediterranean soils. A laboratory study. Geoderma 143(3):273-280

Thonicke K, Venevsky S, Sitch S, Cramer W (2001) The role of fire disturbance for global vegetation dynamics: coupling fire into a dynamic global vegetation model. Glob Ecol Biogeogr 10(6):661-677

Verma S, Jayakumar S (2012) Impact of forest fire on physical, chemical and biological properties of soil: a review. PIAEES 2(3):168-176 
Verma S, Jayakumar S (2015) Post-fire regeneration dynamics of tree species in a tropical dry deciduous forest, Western Ghats, India. Forest Ecol Manag 341: $75-82$

Verma S, Jayakumar S (2018) Effect of recurrent fires on soil nutrient dynamics in a tropical dry deciduous forest of Western Ghats. India J Sustainable For:113. https://doi.org/10.1080/10549811.2018.1453842

Walkley A, Black IA (1934) An examination of the Degtjareff method for determining soil organic matter, and a proposed modification of the chromic acid titration method. Soil Sci 37(1):29-38

Weatherburn MW (1967) Phenol-hypochlorite reaction for determination of ammonia. Anal Chem 39(8):971-974

Whelan RJ (1995) The ecology of fire. Cambridge University Press, Cambridge Wüthrich C, Schaub D, Weber M, Marxer P, Conedera M (2002) Soil respiration and soil microbial biomass after fire in a sweet chestnut forest in southern Switzerland. Catena 48:201-215

\section{Submit your manuscript to a SpringerOpen ${ }^{\odot}$ journal and benefit from:}

- Convenient online submission

- Rigorous peer review

- Open access: articles freely available online

High visibility within the field

- Retaining the copyright to your article

Submit your next manuscript at $\boldsymbol{\sim}$ springeropen.com 